\title{
Methods to overcome dormancy of seeds of Enterolobium schomburgkii (Benth.) Benth. ${ }^{1}$
}

\author{
Antonio Carlos Costa Linhares ${ }^{2}$, Rayssa Gomes Vasconcelos ${ }^{3}$, Silfran Rogério Marialva Alves ${ }^{2}$
}

\begin{abstract}
Enterolobium schomburgkii is an arboreal species, native to the Amazon that presents a wide neotropical distribution. The objective of the present study was to evaluate the effect of different methods to overcome dormancy in E. schomburgkii seeds. The experimental design was entirely randomized, with three treatments and four repetitions of 25 seeds. The methods were (T1) seed coat breakdown opposite the hilum; (T2); seed coat breakdown opposite the hilum + immersion in water for 4 hours and control (T3). The parameters were evaluated: height of the seedlings $(\mathrm{H})$, stem diameter (D), percentage of the emergence of seedlings (E) and the emergence speed index (ESI). The parameters diameter, emergence, and ESI were strongly influenced by the method used to overcome dormancy. The highest values of H, D, E, and ESI were observed in the T2 treatment, due to the time of exposure to water, which provided the acceleration of the emergence of the seedlings. The dormancy of the seeds of E. schomburgkii is overcome with the shoot opposite to the hilum and can be accelerated with immersion in water for 4 hours.
\end{abstract}

Keywords: Forest species; Seed emergence; Degraded areas.

\section{Métodos para superação de dormência de sementes de Enterolobium schomburgkii (Benth.) Benth.}

Resumo: Enterolobium schomburgkii é uma espécie arbórea, nativa da Amazônia que apresenta ampla distribuição neotropical. O objetivo do presente trabalho foi avaliar o efeito de diferentes métodos para superar a dormência em sementes de E schomburgkii. O delineamento experimental foi inteiramente casualizado, com três tratamentos e quatro repetições de 25 sementes. Os métodos foram (T1) desponte tegumentar oposto ao hilo; (T2); desponte tegumentar oposto ao hilo + imersão em água por 4 horas e testemunha (T3). Foram avaliados os parâmetros: altura das plântulas (H), diâmetro do colo (D), porcentagem de emergência de plântulas (E) e o índice de velocidade de emergência (IVE). Os parâmetros diâmetro, emergência e IVE foram fortemente influenciados pelo método de superação de dormência empregado. Os maiores valores de H, D, E e IVE foram observados no tratamento T2, devido ao tempo de exposição à água, o que proporcionou a aceleração da emergência das plântulas. A dormência das sementes de E. schomburgkii é superada com o desponte oposto ao hilo, podendo ser acelerada com a imersão em água por 4 horas.

Palavras-chave: Espécie florestal; Emergência de plântulas; Áreas degradadas.

\footnotetext{
${ }^{1}$ Submitted in 30/05/2020 and approved in 02/07/2020;

${ }^{2}$ Universidade Federal do Amazonas, Faculdade de Ciências Agrárias, Manaus, AM, Brazil. E-mail: linhares.carlos.ac@gmail.com (Corresponding author) - ORICD: https://orcid.org/0000-0002-6764-0358; silfranrogerio@ufam.edu.br - ORICD: https://orcid.org/00000001-5220-234X;

${ }^{3}$ Instituto Nacional de Pesquisas da Amazônia, Programa de Pós-Graduação em Ciências de Florestas Tropicais, Manaus, AM, Brazil E-mail: rayssa.gomesvasc@ gmail.com - ORICD: https://orcid.org/0000-0002-8600-4656
} 


\section{Introduction}

The propagation of native forest species is commonly carried out by means of sexual propagules seedlings (Dantas et al., 2014). However, only about one-third of the seeds of plant species germinate easily, while the others show some degree or type of dormancy (Baskin and Baskin, 2014), such as Enterolobium schomburgkii Benth.

Popularly known as "orelha-de-macaco", this species is native to the Amazon region, with wide distribution in the Neotropical region. It can reach approximately $30 \mathrm{~m}$ in height and is indicated for timber (furniture, civil and naval construction) and recovery of degraded areas (Mesquita, 1990; Lorenzi, 2002). However, the viable seeds of $E$. schomburgkii, even when exposed to favourable conditions, present slow and irregular germination (Rigamonte-Azevedo et al., 2007). As mentioned by Souza and Varela (1999), this is due to physical dormancy in the seeds, imposed by the impermeability of the seed coat to water.

The presence of physical dormancy is recurrent in leguminous forest species, constituting one of the factors of fundamental importance for the success of the implementation and permanence of the species in the field, under conditions of climatic adversity (Montanha et al., 2017). However, for the production of seedlings it is a disadvantageous characteristic, as it can make germination unfeasible or increase the time of seedling formation, resulting in desuniform seedlings (Lemos Filho et al., 1997; RigamonteAzevedo et al., 2007).

This type of dormancy can be overcome by treatments that cause rupture or weakening on the seed coat (Rigamonte-Azevedo et al., 2007). According to Freire et al. (2016), the application of pre-germination treatments, when efficiently performed, favors and accelerates the germination process without damaging the embryonic tissue.

Over the last few years, several methods have been developed in the laboratory to overcome dormancy in E. schomburgkii seeds, such as manual scarification, pointing at the opposite side of the micropyle, immersion in sodium hydroxide and sulfuric acid (Souza and Varela, 1989; Garcia and Azevedo, 1999; Rigamonte-Azevedo et al.,
2007; Araújo et al., 2019). However, the choice of the best method for overcoming the dormancy of seeds of forest species should be determined taking into account the practicality of application and the cost benefit of the method (Silva et al., 2012). Thus, the aim of this study was to evaluate alternative methods for overcoming the dormancy of E. schomburgkii seeds, aiming at obtaining normal and homogeneous seedlings.

\section{Material and Methods}

The experiment was conducted at the Viveiro Florestal da Universidade Federal do Amazonas, Manaus-AM (0306'11.17" S, 59 $\left.58^{\circ} 53.50^{\prime \prime} \mathrm{W}\right)$. The seeds of E. schomburgkii were acquired in the Centro de Sementes Nativas da Amazônia (CSNAM), from a lot with the following characteristics: weight of 1000 seeds $(57.19 \mathrm{~g})$, number of seeds per $\mathrm{kg}(17,438)$, moisture content (11.9\%) (CSNAM, s.d). The seeds underwent the following treatments to overcome dormancy: T1 - seed coat rupture opposed to the region of emission of the radicle; T2 - seed coat rupture opposed to the region of emission of the radicle + immersion in water for 4 hours; T3 Control (without any treatment).

Seeding was performed at approximately $1 \mathrm{~cm}$ depth in individual tublets $\left(60 \mathrm{~cm}^{3}\right)$, containing as substrate, a mixture of clay soil + sand, in the volumetric ratio of 1:0.5 (v:v). The tublets were kept in a nursery with $50 \%$ shading at room temperature. Substrate moisture was maintained through daily irrigation.

The experiment lasted 40 days and the following variables were evaluated: emergency (E\%) - seedlings with cotyledons above the substrate level were used as criteria, according to the Ramos and Ferraz (2008); emergency speed index (ESI) - daily counts were performed, and the index was obtained by the number of emergent seeds (G1, G2,. Gn) each day, divided by the number of days elapsed $(\mathrm{N} 1, \mathrm{~N} 2, \ldots \mathrm{Nn})$ between sowing and emergence (Maguire, 1962); height and stem diameter - at the end of the emergency test, a sampling of 10 normal plants was performed in each repetition, whose height (measured from the stem to the insertion of the last leaf) was measured with the aid of a millimeter ruler, and stem diameter, with a digital pachymeter (Benincasa, 2003). 
The design was adopted entirely randomized, being three treatments with 4 repetitions of 25 seeds each, totaling 100 seeds per treatment. The data were processed in Microsoft Office Excel ${ }^{\circledR}$ 2016 spreadsheets and analyzed using the statistical program SISVAR® (Ferreira, 2008), submitted to analysis of variance and Tukey's 5\% test.

\section{Results and Discussion}

The emergence of E. schomburgkii seeds started from the fifth day after the experiment, resulting in statistically different means for all analyzed variables $(\mathrm{P}<0.05)($ Table 1$)$.

Table 1 Mean values of the variables: emergency speed index (ESI), percentage of emergency (E), height (H), and stem diameter (D) of E. schomburgkii submitted to treatment for dormancy breakage

\begin{tabular}{lllll}
\hline Treatments & ESI & E $(\%)$ & H $(\mathrm{cm})$ & $\mathrm{D}(\mathrm{mm})$ \\
\hline Control & $0,33 \mathrm{c}$ & $33,00 \mathrm{c}$ & $3,88 \mathrm{~b}$ & $2,71 \mathrm{c}$ \\
Tegumentary shoot & $1,32 \mathrm{~b}$ & $72,00 \mathrm{~b}$ & $6,82 \mathrm{a}$ & $3,31 \mathrm{~b}$ \\
Tegumentary shoot + water immersion & $2,95 \mathrm{a}$ & $93,00 \mathrm{a}$ & $7,53 \mathrm{a}$ & $3,76 \mathrm{a}$ \\
\hline Fvalue & $473.068^{*}$ & $219.553^{*}$ & $99.485^{*}$ & $204.137^{*}$ \\
CV $(\%)$ & 7,92 & 6,23 & 6,38 & 2,26 \\
\hline
\end{tabular}

*Averages followed by the same letter in the same column do not differ significantly from each other by the Tukey test at $5 \%$ probability.

The seeds that were not exposed to any treatment (T3) presented the lowest percentage of emergence (E\%) (33\%), compared to the other treatments in which there was seed coat rupture without (T1) and with water immersion (T2), which was 72 and $93 \%$, respectively. These results showed the need for dormancy breakdown of E. schomburgkii seeds, as initially demonstrated by Souza and Varela (1989).

Similar results were reported by other authors such as Ursulino et al. (2019), who observed that the seed coat breakdown followed by immersion in water for 6 hours is the most efficient method for overcoming the dormancy of Dimorphandra gardneriana seeds. In contrast, the results obtained differ from those reported by Rigamonte-Azevedo et al. (2007), who after testing scarification associated with 24,48 , and 72 hours water immersion, do not recommend this type of pre-germination treatment for the species E. schomburgkii. However, shorter soaking times as demonstrated in this study (4 hours) may provide a satisfactory increase in $\mathrm{E} \%$.

Araújo et al. (2019) indicate that immersion in sulfuric acid between 12 to 13 minutes is efficient in overcoming the physical dormancy of $E$. schomburgkii. However, Alves et al. (2008) emphasize that the use of this product requires an appropriate disposal site, besides the difficulty to use it on a large scale, due to the care taken during its handling and the cost, when compared to water treatments.
The time and uniformity of seedling emergence was also influenced by the type of pregermination treatment applied (Figure 1). The T2, where seedling emergence was associated with water immersion, also resulted in the best result for ESI (2.95) followed by T1 (1.32). While at T3 (control), whose emergence was recorded only after 19 days, the ESI was significantly lower (0.33). The ESI and E\% indicate the time needed for the stabilization of the emergency and the percentage viability of available seeds, respectively. Therefore, higher values for this index can be obtained in more vigorous lots (Maguire, 1962) and indicate a shorter time needed for the stabilization of the emergency in seeds.

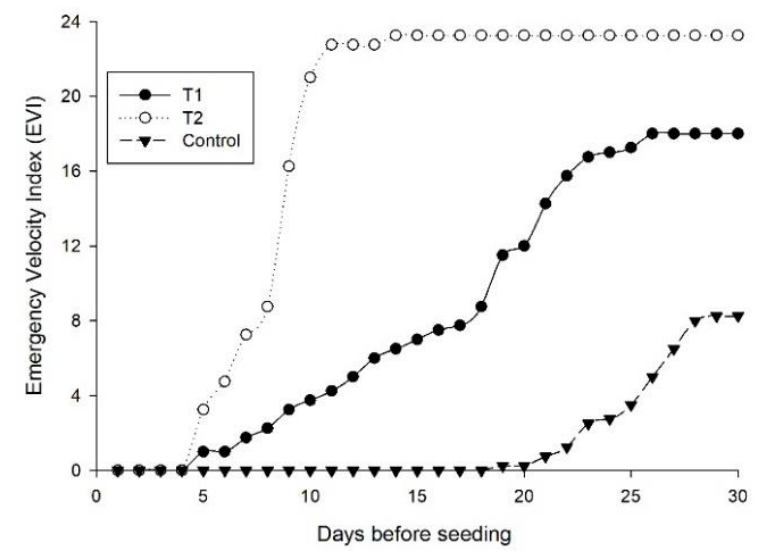

Figure 1 Emergency speed index (ESI), in $E$. schomburgkii seeds submitted to dormancy breakage treatments. 
Regarding the height of the aerial part and stem diameter, the results were also positively influenced by the seed coat breakdown in both treatments ( $\mathrm{T} 1$ and $\mathrm{T} 2$ ). In terms of average percentage there was an increase of $48.47 \%$ in seedling height, compared to T3 (control). The same behavior was observed for the stem diameter, whose mean value recorded for this treatment was also lower than the others. These results corroborate the information obtained for other leguminous such as Dimorphandra gardneriana (Ursulino et al., 2019), Caesalpinia pyramidalis (Alves et al., 2007) and Cassia fistula (Bezerra et al., 2014).

The variables height and stem diameter are important to assess the potential for survival and growth, after planting in permanent area of seedlings of forest species (Scheer et al., 2017). Within the same species, plants with larger diameters also present higher survival. Thus, under the conditions of this study, the application of seed coat breakdown with or without immersion in water is important to estimate the quality of seedlings of E. schomburgkii.

\section{Conclusion}

It can be observed a high efficiency of the treatment with the application of skin shoot followed by immersion in water, indicating this method as viable for overcoming the dormancy in E. schomburgkii seeds.

\section{Acknowledgments}

To the team of the forest nursery of the Universidade Federal do Amazonas, for their support in assembling and monitoring the experiment, and to the Fundação de Amparo a Pesquisa do Estado do Amazonas for granting a scholarship to the first author.

\section{References}

Alves, E. U.; Braga Júnior, J. M.; Bruno, R. de L. A.; Oliveira, A. P. de; Cardoso, E. de A.; Alves, A. U.; Silva, K. B. Métodos para quebra de dormência de unidades de dispersão de Zizyphus joazeiro Mart. (Rhamnaceae). Revista Árvore, v. 32, n. 3, p. 407-415, 2008. https://doi.org/10.1590/S0100-67622008000300003

Alves, E. U.; Cardoso, E. de A.; Bruno, R. de L. A.; Alves, A. U.; Galindo, E. A.; Braga Júnior, J. M. Superação da dormência em sementes de
Caesalpinia pyramidalis Tul. Revista Árvore, v. 31, n. 3, p. 405-415, 2007. https://doi.org/10.1590/S0100-67622007000300006

Araújo, K. V. de; Mota, D. A.; Dobbss, L. B. Escarificação ácida na superação de dormência na superação de dormência de Enterolobium schomburgkii. Revista Agri-Environmental Sciences, v. 4, n. 2, p. 16-23, 2019. https://revista.unitins.br/index.php/agri-environmentalsciences/article/view/734

Baskin, C. C.; Baskin, J. M. Types of seeds and kinds of seed dormancy. In: Seeds. 2.ed. [s.1.] Elsevier, 2014. v. 29, p. 37-77. https://doi.org/10.1016/B978-0-12-416677-6.00003-2

Benincasa, M. M. P. Análise de crescimento de plantas:noções básicas. Jaboticabal: FUNEP, 2003. 42p.

Bezerra, F. T. C.; Andrade, L. A. de; Bezerra, M. A. F.; Silva, M. L. M. da; Nunes, R. C. R.; Costa, E. G. da. Biometria de frutos e sementes e tratamentos pré-germinativos em Cassia fistula L. (Fabaceae-Caesalpinioideae). Semina: Ciências Agrárias, v. 35, n. 4, p. 2273-2286, 2014. https://doi.org/10.5433/16790359.2014v35n4Suplp2273

CSNAM (CENTRO DE SEMENTES NATIVAS DA AMAZÔNIA, BRASIL). Dados de pesquisas não-publicadas. Manaus-Brasil: CSNAM/UFAM, (s.d.)

Dantas, B. F.; Ribeiro, R. C.; Matias, J. R.; Araújo, G. G. L. Germinative metabolism of Caatinga forest species in biosaline agriculture. Journal of Seed Science, v. 36, n. 2, p.194203, 2014. https://doi.org/10.1590/2317-1545v32n2927

Ferreira, D. F. Sisvar: a computer statistical analysis system. Ciência e Agrotecnologia, v. 35, n. 6, p. 1039-1042, 2011. https://doi.org/10.1590/S1413-70542011000600001

Freire, J. M.; Ataíde, D. H. dos S.; Rouws, J. R. C. Superação de dormência de sementes de Albizia pedicellaris (DC.) L. Rico. Floresta e Ambiente, v. 23, n. 2, p. 251-257, 2016. https://doi.org/10.1590/2179-8087.104514

Garcia, L. C.; Azevedo, C. P. de. Métodos para superar a dormência de sementes florestais tropicais. Manaus: Embrapa. p. 1-4.

Lemos Filho, J. P. D. L.; Guerra, S. T. M.; Lovato, M. B.; Scotti, M. R. M. M. L. Germinação de sementes de Senna macranthera, Senna multijuga e Stryphnodendron polyphyllum. 
Pesquisa Agropecuária Brasileira, v. 32, n. 04, p. 357-361, 1997.

Lorenzi, H. Árvores brasileiras: manual de identificação e cultivo de plantas arbóreas do Brasil. 2.ed. Nova Odessa: Instituto Plantarum, 2002. 368p.

Maguire, J. D. Speed of germination-Aid in selection and evaluation for seedling emergence and vigor. Crop Science, v. 2, p. 176-177, 1962.

https://doi.org/10.2135/cropsci1962.0011183X00020002 $0033 x$

Mesquita, A. L. Revisão taxonômica do Gênero Enterolobium Mart. (Mimosoideae) para a região neotropical. 1990. 222p. Universidade Federal Rural de Pernambuco, Recife,

Montanha, D. A.; Arcanjo Alves, J. M.; Silva, M. R. da; Silva Matos, W. da; Oliveira da Silva, D. C.; Barreto, G. F. Superação da dormência e influência da profundidade de semeadura na germinação de sementes de Desmodium tortuosum. Revista AGRO@MBIENTE ONLINE, v. 12, n. 1, p. 34-40, 2017. https://doi.org/10.18227/1982-8470ragro.v12i1.4353

Ramos, M. B. P.; Ferraz, I. D. K. Estudos morfológicos de frutos, sementes e plântulas de Enterolobium schomburgkii Benth. (Leguminosae-Mimosoideae). Revista Brasileira de Botânica, v. 31, n. 2, p. 227-235, $2008 . \quad$ https://doi.org/10.1590/S0100-

\section{5}

Rigamonte-Azevedo, V.; Almeida, M. de C.; Firmino, J. L. Germinação de sementes de timbaúba (Enterolobium schomburgkii BENTH) - Mimosoidae. In: ANAIS DO VIII CONGRESSO DE ECOLOGIA DO BRASIL 2007, Anais. 2007.

Scheer, M. B.; Carneiro, C.; Bressan, O. A.; Santos, K. G. dos. Crescimento inicial de quatro espécies florestais nativas em área degradada com diferentes níveis de calagem e de adubação. Floresta, v. 47, n. 3, p. 279-287, 2017. https://doi.org/10.5380/rf.v47i3.41973

Silva, A. C. F.; Silveira, L. P.; Nunes, I. G.; Souto, J. S. Superação de dormência em sementes de Enterolobium contortisiliquum Mor. (Vell.) Morong. Scientia Plena, v. 8, n. 4, p. 047302, 2012.

https://www.scientiaplena.org.br/sp/article/view/1429

Souza, S. G. A. de; Varella, V. P. Tratamentos pré-germinativos em sementes de Faveiraorelha-de-macaco (Enterolbium schomburgkii, BENTH). Acta Amazonica, v. 19, p. 19-26, 1989.

Ursulino, M. M.; Alves, E. U.; Araújo, P. C.; Alves, M. M.; Ribeiro, T. de S.; Silva, R. dos S. Superação de dormência e vigor em sementes de fava-d'Anta (Dimorphandra gardneriana Tulasne). Ciência Florestal, v. 29, n. 1, p. 105115, 2019. https://doi.org/10.5902/1980509810460 